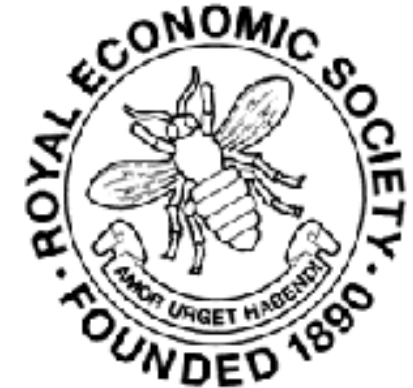

Local Authorities and the Housing Problem in 1901

Author(s): Lettice Fisher

Source: The Economic Journal, Vol. 12, No. 46 (Jun., 1902), pp. 263-271

Published by: Wiley on behalf of the Royal Economic Society

Stable URL: http://www.jstor.org/stable/2957296

Accessed: 31-03-2015 01:55 UTC

Your use of the JSTOR archive indicates your acceptance of the Terms \& Conditions of Use, available at http://www.jstor.org/page/info/about/policies/terms.jsp

JSTOR is a not-for-profit service that helps scholars, researchers, and students discover, use, and build upon a wide range of content in a trusted digital archive. We use information technology and tools to increase productivity and facilitate new forms of scholarship. For more information about JSTOR, please contact support@jstor.org. 
retrograde measure of finance. It is, indeed, surprising that so sober a minister as Sir M. Hicks-Beach should have been induced or forced to sanction a duty of this kind.

C. F. Bastable.

\section{Local Authorities and the Housing Problem in 1901.}

EACH time the general public awakens to the existence of the housing problem-a thing which happens, roughly speaking, about once every ten years - some special aspect of that many-sided question is emphasized, and some particular remedy is advocated. The last two or three years have witnessed one of these outbreaks of popular interest. The feature to which most attention has been paid is that known as the "house-famine," and the remedial measure which has been most widely urged is municipal house building. Articles have appeared in magazines; accompanied by correspondence of a more or less animated nature they have filled columns of local journals and of London papers ; lectures have been given and conferences held all over the country, and some of the results of all this are now apparent. In the first place we have the Housing Act of 1900, which is intended to facilitate municipal building. Secondly, a considerable number of local authorities have been roused to a new or keener interest in the matter, and many fresh schemes have been initiated. The increased amount of space devoted to housing in the pages of that invaluable manual, the Municipal Year Book, is an outward and visible sign of this movement.

Since the passing of the 1900 Act, the London County Council has extended its already extensive operations very considerably. The largest scheme yet undertaken by any local authority was initiated by the London County Council in 1901. 225 acres (costing $£ 400$ an acre) have been acquired at Tottenham, and upon these, in course of time, the Council will provide for 42,500 persons in 5,779 cottages. The Municipal Year Book is enthusiastic-almost poetic-over this scheme, though it honestly informs the inquirer that a financial deficit is expected. It is, in fact, an extremely important matter, and the laying out of the estate, its finances, the class of person accommodated, the comparison of the rents with those in the neighbourhood, the derivation of the tenants, whether they are attracted by the excellent Council buildings from the country or provincial towns, or whether they come from London and relieve the pressure upon more thickly populated districts-all these and many other developments will be watched with much interest. In addition to the Tottenham experiment, schemes at Tooting and at Norbury were proceeded with. The Council expects to provide for about $8 \frac{1}{2}$ thousand people at Tooting, the cottages are to be of four classes, the average weekly rental $7 s .6 d$., and the total cost of the scheme $£ 400,000$. The Norbury site of 31 
acres will provide for 5,800 people in cottages and tenements with weekly rents of from $6 s$. to $11 s$. $6 d$. These large suburban schemes do not by any means exhaust the Council's activities, and it has proceeded with a number of others of varying size and in different parts of London. Theoretically the Council acts upon the sound policy of making the rents cover all expenses, but in practice, it is said, it has occasionally been necessary to wipe off some sums, and several of the buildings show deficits upon the year's working, though it is only fair to add that in the cost of schemes undertaken under Part III these deficits are few and unimportant.

Many of the new London boroughs have embarked upon housing schemes. Marylebone and Shoreditch have acquired sites for buildings to be erected under Part III. of the Act, Stepney intends to house 108 people on the cleared site of Queen's Catherine's Court, Bermondsey is considering possibilities, the medical officer of Finsbury has prepared an important report upon the housing question in his district, Woolwich is meditating over a very extensive scheme. The suburban councils have been no less enterprising. At Barking a block of workmen's dwellings has been opened, Ealing has bought an estate and made plans for cottages with weekly rents of from $9 s$. to $7 s .6 d$. and for flats at $6 s .6 d$. and $4 s .6 d$. Hornsey has a large scheme in hand, and 110 cottages (at $6 s .6 d$. and $8 s .6 d$.) are already occupied, West Ham is famous for the magnitude of its building operations, East Ham is building cottages and contemplates double tenements. Edmonton has purchased an estate of 18 acres, upon which it means to build 400 workmen's dwellings. Southgate possesses twelve cottages let at $7 s .6 d$. and $6 s$. 6d., Barnes 42, which are rented at $7 s$. and $8 s .3 d$. When the rents of these houses are considered, it seems a pity that so many of them should only provide two bedrooms. Of Richmond it is unnecessary to speak, for all who are interested in housing have heard of its cottages. Practically all these schemes provide for the artizan class, and in very few are the rents specially low for the kind of house provided.

In the provinces the year has also been one of activity. The Dryden Street dwellings at Liverpool were opened in the spring. These houses, which have been referred to as models by several inquiring municipalities, were erected upon cleared sites, and are meant to provide for the really poor labouring class. The houses are three stories high, and contain 182 tenements of different sizes. The six four-roomed tenements are each let at $6 s$. a week, the sixteen three-roomed at $4 s .6 d$., and the others, which are all of two rooms, at $3 s$. and $4 s$. An interesting experiment has been made by providing (in the block which contains the caretaker's dwelling) a large recreation room for the use of the tenants. In the same block is a boiler house, from which hot water is laid on to all the tenements. By August the Committee had had over 300 applications for the Dryden Street houses, but most of them had to be refused, either because the applicants had 
not been dispossessed by the clearances of the Council, or if they had, they were unable to pay the rents required, or else their families were too large. Most difficulty was experienced in letting the two-roomed tenements, and the Housing Committee have therefore resolved to build more three-roomed houses in future. The problem of how the really poor are to pay the rents of these is not, however, much nearer solution. It is hoped that the rents will cover all expenses, but this has not been the case in most of the Council's building experiments. During the year the clearances and demolition of insanitary property went on steadily, and in July the Housing Committee issued an important report, which estimated the number of insanitary houses remaining at 7,500, 15 per cent. of which could be dealt with by means of closing orders. In the course of the year there were animated discussions as to the policy which should be followed by the Council in dealing with this insanitary property. There was a strong body of opinion in favour of building in the suburbs, there was much doubt as to the proportion of the displaced which should actually be rehoused by the Council. The chairman of the Committee pointed out that about a million and a half would have to be spent upon clearances and demolitions, and that the erection of the five thousand houses which would be required were a large proportion of the displaced to be rehoused would involve a $6 d$. rate. The general conclusion was that suburban houses might safely be left to private enterprise, that the Council should rehouse, usually upon the spot, in tenement houses, persons who were actually displaced by their demolishing operations, and that the building schemes actually in hand should be proceeded with as rapidly as possible. In September an improvement scheme under Part I of the Act was adopted by the Council. This will involve displacing about 3,200 persons, its estimated cost is $£ 70,990$, and some of the very worst slum areas of the city will be dealt with. The scheme involves a new departure, for, with the exception of the clearance undertaken in 1876 under Cross's Act, demolitions have hitherto been accomplished through the powers conferred upon the Corporation by local Acts. The net result of the housing policy pursued by Liverpool during the last two or three years seems to be that the court houses, which are its peculiar disgrace, will be eliminated comparatively rapidly, though at considerable cost, that a very large population of the poor labouring class will be rehoused in the centre of the town, mostly in two and three-roomed tenements, and finally, that either the poorest of them will not be rehoused at all, or else that an extremely heavy burden will be placed upon the rates. Probably a middle course will be pursued, and the poor, but not the poorest, will be housed partly at the expense of the ratepayers. In any case, Liverpool has decided to undertake a very considerable and important task, and also to perpetuate the dwellings of the poor in those parts of the city where land is most valuable.

In Birmingham and in Manchester highly important schemes have 
been initiated, but in both cases the basis of the housing policy has been exactly opposite to that of Liverpool, for the two most important proposals have been for large schemes of suburban buildings. In 1900 the Manchester Council decided to purchase an estate of 237 acres at Blackley. The property is situated on the extreme limit of the city boundary, and it will be rendered accessible by a branch railway already proposed by the Lancashire and Yorkshire railway companies, and by the coming electric tramways. It is rather less than four miles from the centre of the city. The idea of the Council was to use part of this land, of which the purchase was completed early in 1901, for allotments, and to erect cottages upon the rest. There were, of course, considerable objections to this scheme. Its opponents pointed out that the difficulty in Manchester, as elsewhere, is the housing of the really poor, and that the poor will scarcely ever consent to live on the outskirts of a city, but cling to their old haunts near the centre. There was no special need of artizans' dwellings, but cottages erected at Blackley, if they were inhabited by Manchester people at all, and not by denizens of Middleton and other places which are nearer the site than is Manchester, would inevitably be taken by artizans. The cost of rent and transit together would be far more than any of those who were really in need of housing could easily pay. Despite these and other objections, the purchase was duly completed, an application was made to the Local Government Board for borrowing powers, and plans were prepared for the laying out of the estate and for the proposed cottages. The original plans provided for long rows of small cottages, and to these very strong objection was taken. The Citizen's Housing Committee, a powerful and important body, eventually met the Sanitary Committee upon the matter, and the plans underwent considerable modifications. Instead of building all the houses of one type-two rooms upstairs and two down-it was finally decided to erect houses of four kinds. Class A will contain a sitting room, living room, three bed rooms and bath room, 56 will be built, at an estimated cost of $£ 237$ each; Class B, of which there will be 55 , at an estimated cost for each house of $£ 246$, contains a living room, scullery, three bed rooms and bath room. Class $\mathrm{C}$ are of the same design as $\mathrm{B}$, but differently arranged. 38 of them are to be built in terraces at $£ 242$ each, and 22 in semi-detached form at $\$ 255$ each. Lastly, there will be 22 of Class D, the original four-roomed type, costing $£ 210$ each. The main road which runs through the estate will be 20 yards wide, and will be planted with a double row of trees, the side streets will be 10 yards wide. All the houses have open spaces in front and behind. The total cost of the scheme is estimated (excluding the cost of the land) at $£ 62,605$, a sum which will probably be exceeded, as it is based upon the original and not the altered estimate for forming and sewering streets. The final arrangements were made in December, and in the course of the present year probably some of the cottages will be erected. No estimate has yet been made 
of the rents to be charged. It should, however, be noticed that the workmen's dwellings already possessed by the Manchester Council involve a charge upon the rates. Manchester has tried experiments of several kinds, and has built block dwellings, cottages, and tenement houses, but there is a yearly deficit on all the schemes, apart from the large sum quite properly charged to the rates as due to sanitary improvements. For the purposes of valuation the Sanitary Committee has fixed $10 \mathrm{~s}$. a square yard for land actually occupied by dwellings, and $30 \mathrm{~s}$. a square yard for land occupied by shops as the price upon which the financial statements are based, and the cost of the land thus excluded from the accounts amounted, for five schemes (the figures for the Harrison Street lodging house were not available, and in any case would not be of importance, as the building has only recently been opened) to $£ 106,0928 s$. $8 d$. In addition to this, there was in the financial year ending March, 1901, a deficit-an excess of expenditure over receipts from rents - of over $£ 3,000$, a sum which seems large, but is not really so great as that of many of other local authorities which have built workmen's dwellings, when the very considerable magnitude of the Manchester schemes is allowed for. Salford has also an extensive scheme in hand for building artizans' cottages upon a large site (eleven acres) formerly occupied by barracks.

The housing problem in all its aspects was very hotly discussed in Birmingham last year. A prominent local journal published in the spring a series of highly-coloured articles, depicting the horrors of slum life in Birmingham-and it must be remembered that the slums of that city are of a very deplorable character. Considerable popular interest was aroused by these articles and by lectures and addresses which were given. In its early days Birmingham was regarded as almost a model city, from the housing point of view, and except for the great improvement scheme carried out under Mr. Chamberlain's auspices, in 1875, but little had been done. In 1892 some workmen's dwellings were erected, in 1899 more, and lastly great trouble was taken to provide for the very poor, which resulted in the Milk Street dwellings. These, though not so cheap as the Gildarts Gardens houses in Liverpool, have done something towards meeting the needs of the really poor. In 1901 the Housing Committee (a temporary body consisting of members of the Health and Estates Committee) had in hand two further schemes. One was for an experimental block of flats in the centre of one of the poorest quarters of the town, the other for a large scheme of surburban buildings. Seventeen and a half acres had been purchased at Bordesley Green, about three miles from the centre of the city, at a cost of about $£ 6,200$, and upon this estate the Committee proposed to erect some 500 cottages. Both schemes encountered storms of opposition. The mere mention of "flats" is enough to rouse the wrath of a considerable portion, especially of the artizan class, of the Birmingham population. On the other hand the opponents of the Bordesley Green scheme pointed out that there already existed a 
large number of untenanted small houses in the suburbs, which had been built at the height of the cycle boom and were no longer required. Moreover, it was said that if the Council would initiate a vigorous tramway policy (the tramways are at present leased) suburban houses of all kind and sizes would certainly be built without any municipal interference. Local journals threw themselves into the fray, and the housing issues became associated with party politics. The only policy for which there was no great outcry was the commonsense but perhaps dull one-from a newspaper point of view-of a sound and vigorous administration of the sanitary laws, a policy which to the impartial observer seems on the whole best fitted to meet the needs of the Birmingham case. Eventually both schemes were dropped, and it was arranged that a new Housing Committee, not a temporary body, should be appointed after the November elections, and that all problems should be left to it to solve. The personnel of this body, when it was appointed, was almost entirely new, and great hopes were entertained by its supporters. It remains to be seen what measures it will take. Meanwhile, however, one definite and excellent result of the movement had been arrived at, in the appointment of a strong voluntary Sanitary Aid Committee, which is to work through local committees in the same way as the admirable Mansion House Council. Of other recent schemes, perhaps the most important is the large clearance projected by the Bradford Town Council. The Longlands insanitary area was the subject of a representation from the medical officer in 1898, when it was pointed out that there were 301 persons to the acre, and a death rate of over 40 in the thousand. The Council, after some hesitation, have at last decided to clear the whole area, which contains about 22,650 square yards and 284 houses. Part of the site is to be set aside for commercial buildings, and upon the rest it is proposed to erect three-story tenement houses, upon much the same lines as those at Manchester and Liverpool. There are to be 88 two-roomed tenements, 36 single-roomed, and 22 four-roomed, which will accommodate altogether 432 persons. The rent, allowing 35 per cent. of the gross rental for maintenance and outgoings, will be, if the loan is obtained for 60 years, $5 s .1 d$. for four rooms, $2 s .7 d$. for two, and $1 s .6 d$. to $1 s$. $8 d$. for one. If, however, the capital has to be repaid in 40 years the rents are estimated at $6 s .2 d ., 3 s .1 d$., and $1 s .10 d$. to $2 s$. The remainder of the displaced population are to be provided for on another site, which is about two miles distant, but is on the tramline. Here it is proposed to erect a number of self-contained five-storied houses sufficient to accommodate 798 persons. The rents for these will be $5 s .3 d$. or $6 s$. $4 d$., according to the number of years over which the repayment of the loan is spread. For the purpose of estimating the rents, the ground is valued at $5 s$. a square yard, and the remainder of the cost, which will be charged upon the rates as a sanitary improvement, is estimated at $£ 28,204$.

Most large ports suffer from specially acute forms of the housing 
problem. Many of them have congested areas covered with old and insanitary buildings, and all have large numbers of intermittently employed persons of the dock-labouring class. In Plymouth and Devonport the problem is of peculiar difficulty, partly on account of the configuration of the land, which makes extension almost impracticable. The Plymouth Corporation have in hand a large scheme for erecting workmen's dwellings upon the Prince Rock Estate. In the older blocks the tenements let readily, but the rents fixed were insufficient to cover the expenditure, the deficit amounting to about $£ 2,000$. It was decided to let the buildings, finished last year, at rents which would cover all expenses, and these were fixed at $6 s$. for three rooms, and $4 s$. $6 d$. for two. It was, however, found very difficult to obtain tenants at these prices. The whole housing question was much discussed during the year, especially at the time of the municipal election.

At Devonport equally great difficulties have been experienced. The Committee recommended the Council to build houses for 252 families upon what is known as the Cemetery site. This scheme however was not popular. The shopkeeping class opposed it because the site was too near Plymouth, and buildings upon it would tend to transfer custom from the Devonport shops to those of Plymouth. Further it was said that there were already many vacant houses in the suburbs, the site was too far off to be useful, and the only practicable plan was to reconstruct the old and dilapidated parts of the town. The Chairman of the Committee, who was much respected locally, was absent when the scheme was proposed to the Council, and almost immediately afterwards resigned in consequence of his opposition to the scheme. Under all these circumstances it was found expedient to withdraw it, and the housing question is still perplexing the Devonport councillors.

The Southampton Town Council are struggling with a clearance and housing scheme initiated some years ago. Loans were raised for a scheme dealing with about 30 acres of land, which land is in proces; of being cleared, and upon it the Corporation erected a men's lodging house with 186 beds (at $6 d$. each a night), which was followed by blocks of artizans' dwellings. Financially, these buildings have scarcely been a success, the original estimates were exceeded, the rents are somewhat high $(8 s .6 d$. for three rooms, and $6 s$. 6d. for two) and leave, after interest and sinking fund have been paid, an extremely narrow margin for repairs, rates, and other outgoings. In the financial year ending March 31st, 1901, there was a deficit upon both the block-tenements and the lodging-house; moreover, some difficulty was experienced in letting the tenements and filling the lodging-house. A number of schemes for rehousing the rest of the displaced population were considered, but none seemed wholly satisfactory, and finally, in December, the Council agreed to postpone the consideration of the matter for six months.

At Newcastle-on-Tyne the housing problem is a very serious one. A 
special Committee of the Town Council has been appointed to examine into and report upon it. The question is also under consideration at Bristol. The committee of inquiry appointed by the Town Council of Wolverhampton issued a comprehensive report in the course of the year, and a small experimental building scheme has been decided upon. The Council are fortunate in being able to obtain a convenient site of 4,000 square yards at the very moderate price of $2 s .9 d$. a square yard. Upon this land they propose to erect 50 cottage tenements, half of two rooms and half of three. They hope to let these at $2 s$. and $3 s .8 d$. weekly, but it remains to be seen whether this hope will be fulfilled when the buildings are finished.

At Nottingham an important report has been issued, and is now under consideration. The report recommended the erection of some experimental three-story dwellings, containing six four-roomed tenements at $6 s$. weekly, twelve three-roomed at $4 s$. $6 d$., and twelve tworoomed at $3 s$. These sums are expected to cover all expenses except the sinking fund. The council were also advised to deal with one of the large insanitary areas of the town. The report excited a considerable amount of interest, and the housing question has been the subject of voluminous correspondence in the local papers.

Many other local authorities are contemplating building schemes, either as a new departure or as an enlargement of former schemes. Bath is erecting forty workmen's dwellings and has a scheme for forty more. Birkenhead has decided to undertake a third improvement scheme, which deals with five insanitary areas containing 5,576 square yards and 150 houses. Brighton has spent large sums upon clearances, and has erected five-roomed cottages upon a site presented to the council for the purpose. The cottages are rented at $7 s .6 d$., a sum which is insufficient to cover expenses. Burton-on-Trent is carrying out a scheme under Part III for the erection of 151 dwellings : an annual deficit of about $£ 230$ is expected. Bury contemplates the erection of a lodginghouse, but has hitherto contented itself with carrying on very useful work under Part II of the Act. At Erith forty-eight cottages are in process of construction, and some of these are now completed. Hull is another of the towns which has hitherto succeeded in performing all necessary clearances under Part II, though in order to comply with Local Government Board requirements as to rehousing, it has recently erected a block of forty tenements. Leicester has adopted Part III, has built forty-two tenements, in the course of which process many unexpected difficulties occurred, and lets them at 3s. to $4 s$. $1 \frac{1}{2} d$. for a living-room, scullery and bedroom, and $4 s$. to $5 s .1 \frac{1}{2} d$. for a tenement with two bedrooms. Sheffield is carrying out by degrees a plan prepared some two years ago under Part III. Yarmouth is building workmen's cottages and closing insanitary houses. Tunbridge Wells about two years ago bought three acres with a view to building, but has been unable to arrive at any further decision. Several other authorities-for instance, Bonsall, Cheltenham, Coventry, Dudley, 
East Grinstead, Hertford, Lichfield, Morpeth, Newport (Mon.), Rotherham, Stanley, Wellington, have adopted Part III, and some of them are either preparing or carrying out building plans. In many others the matter is under consideration, and there are occasional discussions in the councils and occasional articles or letters in the local papers. Some district councils, for instance, the Consett U.D.C. and the Spalding R.D.C., are about to take action under Part III. Several important towns are carrying out clearance schemes, and are content to work fairly slowly and not to plunge into building. The most important of these is perhaps Leeds, which for many years was one of the most insanitary cities in England, but is now engaged in a steady clearance of its slums, a very large number of which have recently disappeared. The Council does not find it necessary to build.

On the whole the general movement towards municipal building, which seems to be specially noticeable in the last few years, has spread also to Scotland and Wales. In England it has been very marked. What will be the result of all this action? Many questions suggest themselves to the inquirer. It is in the first place important to notice that very few local authorities are able to make the rentals of their houses cover all expenses, and there is usually a deficit, more or less serious, which has to be met by the rates. How far is this rateaided building likely to compete with private enterprise? What will be the ultimate effect upon the total supply of houses? How many houses, and of what kind, can a local authority safely build without interfering with private enterprise? Will local authorities rest content with trying experiments and setting examples, or will one scheme beget another, and the pressure upon the Council involve it in huge enterprises, as seems likely to be the case, for instance, in Liverpool, Glasgow, and London? What will be the effect of rate-aided buildings upon wages? What sort of citizens will municipal tenants make, and what will be the effect of a solid body of persons whose interests as tenants may quite conceivably outweigh the interests of their neighbours as ratepayers? How heavy a rate will the average ratepayer put up with for housing purposes? Which of the many different policies will local authorities pursue? Will they, like Sheffield, Manchester, and (partly) the London County Council, endeavour to create suburban colonies of workmen's dwellings, or, like Liverpool, will they keep the casual and intermittent labourer in artificially cheapened houses built upon dear central land? These and many other questions arise inevitably from a careful survey of a movement regarded by many as hopeful, by many as somewhat dangerous, but by every one who considers it at all as extremely interesting and important.

Lettice Fisher 